DOI: 10.19195/0137-1150.163.34

\author{
ALBERT NOWACKI \\ Katolicki Uniwersytet Lubelski Jana Pawła II, Lublin, Polska \\ albert.nowacki@kul.pl
}

\title{
Młodość wobec starości: szacunek czy deprecjacja? Namir! Lubka Deresza
}

Zagadnienia związane ze starością i starzeniem zawsze znajdowały się w sferze zainteresowań ludzkich, jest to bowiem odwieczny i nieustannie obecny temat kultury. Na przestrzeni kolejnych stuleci topika starości obecna była w kulturze i literaturze każdego niemal narodu, choć jak zauważa Agnieszka Czyżak, jej tekstowe realizacje pojawiały się ze zmienną intensywnością ${ }^{1} \mathrm{i}$, dodajmy, przyjmowały ewoluujące formy. Działo się tak, gdyż ludzkie podejście do osób starszych od zawsze cechowało się skrajną ambiwalencją. $Z$ jednej strony osobę taką czczono i otaczano szacunkiem, z drugiej zaś, jak pokazuje historia ludzkości, skazywano na samotną egzystencję lub śmierć.

W społeczeństwach pierwotnych status starców bywał heterogeniczny, zależał bowiem od sposobu życia i ogólnego porządku danej kultury. W niesprzyjających okresach głodu i w obliczu innych zagrożeń to właśnie ludzie starzy, a zwłaszcza chorzy i niedołężni, cierpieli najbardziej. W takich momentach, pozbawieni pomocy ze strony rodziny, najczęściej uznawani byli za jednostki bezproduktywne, a zatem bezużyteczne i niepotrzebne. Bezwzględnością charakteryzowały się zwłaszcza ludy koczownicze, które miały w zwyczaju zabijanie starców niebędących w stanie nadążyć za swoją gromadą, ponieważ opieka nad jednostkami niesamodzielnymi mogła oznaczać zmniejszone szanse na zdobycie pożywienia, a to stwarzało bezpośrednie zagrożenie dla całej gromady ${ }^{2}$. Trzeba było dopiero postępu gospodarczego, żeby ludzkość doceniła ludzi starszych i zaczęła obdarzać ich szacunkiem. Z upływem czasu pozycja osób starszych ulegała zmianie, co najbardziej widoczne było w kulturach tradycyjnych, w których wiedzę przekazywano z pokolenia na pokolenie, z ust do ust. W tych okoliczno-

${ }^{1}$ A. Czyżak, Na starość. Szkice o literaturze przełomu tysiacleci, Poznań 2011, s. 5.

${ }^{2}$ Zob. E. Rosset, Miejsce człowieka starego w społeczeństwie, [w:] Encyklopedia seniora, red. I. Borsowa, W. Pędlich, J. Piotrowski, Warszawa 1986, s. 20-26. 
ściach pozycja seniorów rosła, byli oni bowiem nosicielami wiedzy praktycznej dzięki swemu wieloletniemu doświadczeniu. Oni też stali na straży obyczajowości, tradycji i tożsamości danej społeczności, w związku z czym, jak podaje Ewa Nowicka, ich pozycja ekonomiczna była w pewnym sensie najwyższa ${ }^{3}$. Wzrost prestiżu starców zauważalny był już w starożytnej Grecji i Rzymie, gdzie funkcje polityczne powierzano mężczyznom, którzy ukończyli sześćdziesiąt lat, albowiem wedle przekonania ówczesnych odznaczali się doświadczeniem i mądrością życiową ${ }^{4}$. Henryk Podbielski uważa, że potwierdza to nawet etymologia używanych na oznaczenie starości i starca greckich wyrazów „geras” ( $\left.\gamma \eta \rho_{\rho} \alpha \varsigma\right)$ i „geron” ( $\gamma \varepsilon ́ \rho \omega v)$, które wywodzą się od tego samego źródłosłowu, używanego na oznaczenie zaszczytów ${ }^{5}$. Z drugiej jednak strony Anna Zmorzanka przypomina, że nastawienie pisarzy greckich doby helleńskiej do osób w podeszłym wieku było ambiwalentne, gdyż jak twierdzi badaczka, ,jedni przeklinali starość, a wszelkie jej oznaki ośmieszali, inni mówili o szacunku należnym ludziom starszym, do którego też nawoływali’”. Na przestrzeni kolejnych wieków pozycja osób starszych w hierarchii społecznej ulegała dalszym zmianom, między innymi tym związanym z wynalezieniem i upowszechnieniem druku, co pozwoliło na zdjęcie ze starości nimbu skarbnicy pamięci i tożsamości społeczeństwa. Słuszną uwagę poczynił Jean Delumeau, przypominając, iż „ewolucja starości i jej statusu nie przebiegała w sposób liniowy", co więcej

miejsce, jakie przyznawano starości, i sposób, w jaki na nią patrzono, zależało od wielu czynników, między którymi mogły zachodzić rozmaite, mniej lub bardziej skomplikowane, powiązania; czynniki te to strukturalny układ społeczeństwa, rola przekazu mówionego i pisanego, rozmiary rodziny — od patriarchalnej lub dwupokoleniowej — akumulacja mienia ruchomego, ideał urody, który z kolei podlegał lub nie podlegał koncepcjom religijnym ${ }^{7}$.

Starość często kojarzono z chorobą, słabością, brzydotą i cierpieniem, jednak wzrost demograficzny na przełomie XVIII i XIX wieku spowodował, że przestała ona być zjawiskiem marginalnym, a zmieniająca się długość życia ludzkiego sprawiła, że granica wieku podeszłego zaczęła się przesuwać. Obecnie sytuacja osób starszych wciąż pozostaje niejednoznaczna, na co zwrócił uwagę Anthony Giddens, pisząc, że w społeczeństwach nowoczesnych seniorzy sytuowani są o wiele niżej i mają mniej władzy niż w kulturach przednowoczesnych ${ }^{8}$.

Rozważania o starości byłyby niepełne bez próby ustalenia jej progu. Okazuje się, że na przestrzeni swych dziejów ludzkość różnorako wyznaczała granicę,

${ }^{3}$ E. Nowicka, Świat człowieka - świat kultury, Warszawa 2004, s. 345.

${ }^{4}$ M. Modrak, Trzeci poziom dojrzałości. Szczęśliwe życie po sześćdziesiatce, Gliwice 2013, s. 14.

${ }^{5}$ H. Podbielski, Starość i starcy w poematach Homera, [w:] Dojrzewanie do petni życia. Starość w literaturze polskiej i obcej, red. S. Kruk, E. Flis-Czerniak, Lublin 2006, s. 60.

${ }^{6}$ A. Zmorzanka, Platon o starości i ludziach starych, „Vox Patrum” 56, 2011, s. 73.

7 J. Delumeau, Przedmowa, [w:] G. Minois, Historia starości. Od antyku do renesansu, Warszawa 1995, s. 6-7.

${ }^{8}$ A. Giddens, Socjologia, Warszawa 2008, s. 184. 
za którą zaczynała się starość, gdyż zmieniała się średnia długość ludzkiego życia. W epoce brązu i żelaza ludzie żyli przeciętnie około osiemnastu lat, z czasem długość ich życia zaczęła się zwiększać. W starożytnym Rzymie świat obywateli dość stereotypowo podzielono na iuniores i seniores; jak twierdzi ks. Jerzy Jurkiewicz, „zazwyczaj starość była przedstawiana jako wiek mądrości, a młodość jako wiek opanowany namiętnościami"9. Zgodnie z zasugerowanym przez Pitagorasa podziałem faz życia człowieka Grecy ustanawiali próg starości na sześćdziesiątym roku życia, choć Plutarch uważał, że to granica lat pięćdziesię$\mathrm{ciu}^{10}$. W świecie rzymskim funkcjonowała klasyfikacja Warrona, zgodnie z którą rozróżniano kilka etapów życia ludzkiego, w tym senectus — etap starości sytuowany między czterdziestym piątym a sześćdziesiątym rokiem życia oraz senius — rozpoczynający się od ukończenia sześćdziesiątego roku życia i trwający aż do śmierci okres późnej starości połączonej z niedołęstwem i niemocą starczą ${ }^{11}$. Jak podaje Georges Minois, św. Izydor z Sewilli był skłonny uważać, że starość rozpoczyna się dopiero po przekroczeniu wieku siedemdziesięciu lat i zmierza ku fazie zdziecinnienia ${ }^{12}$. Można powiedzieć, że w zasadzie aż do czasów rewolucji przemysłowej postrzeganie starości i jej progu niemal nie uległo zmianie, wciąż bowiem średnia długość życia nie była imponująca, wynosiła bowiem nieco ponad czterdzieści lat. We współczesnym świecie, w którym przeciętna długość życia to sześćdziesiąt pięć-siedemdziesiąt lat, początkiem starości w rozumieniu kulturowo-obyczajowym wciąż pozostaje przysłowiowy „szósty krzyżyk”, lecz wydaje się, że zarówno z punktu widzenia systemu emerytalnego (podniesienie wieku emerytalnego do sześćdziesięciu siedmiu lat w większości państw UE), jak i dzięki rozwojowi medycyny i zwiększaniu się długości życia ludzkiego granica ta musi ulec przesunięciu, gdyż zgodnie z analizami instytucji państwowych, w roku 2050 średnia długość życia wynosić będzie siedemdziesiąt pięć lat ${ }^{13}$.

Motyw starości od zawsze funkcjonował w literaturze światowej. W swej twórczości wykorzystywali go nie tylko pisarze antyku, lecz także autorzy tworzący we wszystkich kolejnych stuleciach. Kwestię starości i znaczenia nabywanej z wiekiem mądrości porusza już biblijna Księga Koheleta, choć jak pisze Georges Minois,

problem starości wyraźnie nie interesował chrześcijańskich autorów. W ich dziełach starcy byli niemal nieobecni; aby zgromadzić skromny materiał na ten temat, trzeba przeczytać setki tomów ${ }^{14}$.

Dla pisarzy i myślicieli wczesnego średniowiecza starość była zaledwie symbolem, przy czym warto podkreślić, że nie tylko symbolem mądrości, albowiem

${ }^{9}$ Ks. J. Jurkiewicz, Kiedy w starożytności rozpoczynała się starość?, „Vox Patrum” 56, 2011, s. 190.

10 Zob. ibidem, s. 190-191.

11 Ibidem, s. 193.

12 G. Minois, op. cit., s. 129.

13 A. Dragan, Starzenie się społeczeństwa polskiego i jego skutki, „Opracowania Tematyczne" OT-601, Kancelaria Senatu, Biuro Analiz i Dokumentacji, kwiecień 2011, s. 3.

${ }^{14}$ G. Minois, op. cit., s. 128. 
poprzez swoją zgrzybiałość i brzydotę starość bywała też alegorią grzechu ${ }^{15}$. Osobowość starszym ludziom przyniosły dopiero zmiany demograficzne w XIV i XV wieku, kiedy na skutek zarazy i konfliktów zbrojnych znacząco wzrósł odsetek ludzi starych w społeczeństwie. Seniorów zaczęła zauważać nie tylko machina państwowa (pobór podatków „od głowy”), lecz także literatura, choć należy przyznać, że najczęściej eksponowano konflikt pokoleń powstały wskutek skupienia majątku i władzy w rękach starszyzny ${ }^{16}$. Wspomniany temat na dobre zagościł dopiero w literaturze przełomu XVIII i XIX wieku. Wraz z nastaniem epoki romantyzmu i pojawieniem się Fausta Johanna Wolfganga Goethego znów zwrócono uwagę na to, że starość nie oznacza już tylko utraty nadziei na spełnienie. Tytułowy Faust starał się przecież zaznać szczęścia pomimo zaawansowanego wieku, a swoje plany zamierzał zrealizować, pracując na rzecz innych ludzi. Można by przy toczyć również bliższy nam przykład Pana Tadeusza Adama Mickiewicza, który stworzył postacie Gerwazego i Protazego, uosabiających wierność i oddanie, oraz postać Sędziego - ideał wiernego swej ojczyźnie patrioty. Najbardziej jednak jaskrawo motyw starości eksploatuje literatura XX wieku, choć przyznać należy, że funkcjonująca dotychczas w literaturze koncepcja opozycji młodości wobec starości, rozumiana jako konfrontacja atrakcyjności i siły z mądrością uzyskaną dzięki doświadczeniu, która swe korzenie wywodzi jeszcze z czasów antyku, uległa istotnej przemianie. Wiek XX przyniósł bowiem kult młodości zbuntowanej, który jak stwierdza wspominana już Agnieszka Czyżak, wyparł ,zapotrzebowanie na tworzenie kreacji czy autokreacji starego artysty zmagającego się z okrutną naturą" ${ }^{17}$. Jednocześnie $\mathrm{z}$ apologią młodości narodziło się wstydliwe ukrywanie starości, lęk przed samotnością i wykluczeniem osób starszych ze społeczeństwa, podsycany dodatkowo przez kulturę masową. Przyszedł nareszcie czas, gdy literatura przestała interesować się starością. Nie znaczy to jednak, że sylwetki seniorów przestały pojawiać się w dziełach literackich, przeciwnie: zawsze były i pozostaną w nich obecne. Przywoływana A. Czyżak zwraca jednak uwagę, że „wykluczona została starość jako temat nośny artystycznie, przekazujący wiedzę o ludzkiej egzystencji i predystynacji”, z kolei „twórcy wykorzystujący tradycyjne rozwiązania literackie nie postrzegali starości jako tematyki ważnej, jak gdyby odwieczna opozycja starości i młodości została ostatecznie zredukowana do jednego członu - zgodnie z zapotrzebowaniem odbiorców łaknących dionizyjskiego święta, odrzucających apolliński ład świata"18. Musiał dobiec końca wiek XX, by w opisywanym procesie zaszły zauważalne zmiany. Każdy bowiem schyłek wieku przynosił częstsze niż zazwyczaj występowanie motywów egzystencjalnych, co zaowocowało literackimi przedstawieniami doświadczenia starości jako wizji dożywania, ale też godnego

15 Ibidem, s. 133; por. także: W. Menninghaus, Wstręt. Teoria i historia, Kraków 2009, s. $110-122$.

16 G. Minois, op. cit., s. 252.

17 A. Czyżak, op. cit., s. 40.

18 Ibidem, s. 41. 
przeżywania starości. Warto w tym miejscu wspomnieć jeden $\mathrm{z}$ utworów będących już kanonem literatury zachodniej, jakim jest powieść Ernesta Hemingwaya Stary człowiek i morze. Jej bohater w sposób godny podziwu zmagał się ze swą starością i udowadniał, że w jego wieku człowiek wciąż pozostaje bytem wartościowym.

Jeśli w kontekście dotychczasowych rozważań popatrzymy na literaturę ukraińską ostatnich dziesięcioleci, to możemy dostrzec, że wpisuje się ona w ogólne tendencje literatury europejskiej, choć ma także własną specyfikę. Jako jeden z pierwszych postać starca w charakterze symbolu mądrości wykorzystał wybitny pisarz i filozof ukraiński Hryhorij Skoworoda ${ }^{19}$. Należy też zauważyć, że ten wędrowny filozof ukraiński jest również autorem przekładu utworu Marka Tuliusza Cycerona Cato Maior de senectute, przy czym był to nie tyle przekład sensu stricto, ile raczej autorska interpretacja idei rzymskiego myśliciela, prowadząca do rozważań o starości jako ,jesieni życia”20.

Nieco później, częściowo będąc także pod wpływem Skoworody, po motyw starca jako mędrca, nosiciela pamięci narodowej i strażnika historii sięgali tacy pisarze, jak na przykład Taras Szewczenko. Historycy literatury przyznają mu rolę nowatora w poezji ukraińskiej, jednakże często nie dostrzega się, że ten ukraiński wieszcz narodowy dość dużo uwagi poświęcił również zagadnieniom starości. Fakt ten należałoby traktować jako swoiste novum w ukraińskiej przestrzeni literackiej, albowiem poezja ludowa, z której Szewczenko czerpał tak obficie, motywy starości niemal zupełnie omijała. W wielu swych utworach pisarz dawał dowód na to, że niedola ludzi starszych nie była mu obojętna, ubolewał nad losem ubogich kobiet-wdów, jednak największą uwagę przyciąga utwór Perebendia (Перебендя, 1839), w którym poeta stworzył postać starego kobziarza snującego barwne opowieści o wielkiej ukraińskiej przeszłości.

W rozważaniach o motywach starości w literaturze ukraińskiej nie sposób pominąć wybitnej poetki i dramatopisarki Łesi Ukrainki, która w swym dramacie Pieśni lasu (Лісова пісня, 1911) stworzyła postać wujka Lwa. We wspomnianym utworze ten ,[...] старий чоловік, поважний і дуже добрий з виду”21, nie tylko odegrał rolę nauczyciela i przewodnika dla Łukasza, lecz ze względu na nieskalany charakter i wielkie życiowe doświadczenie także był gwarantem równowagi pomiędzy światem duchowym i materialnym. W podeszłym wieku są też niektórzy bohaterowie powieści Iwana Neczuja-Łewyckiego (Кайдашева сім'я, 1878; Хмари, 1874; Баба Параска та баба Палажка, 1974). W tym miejscu warto zwrócić szczególną uwagę na ten pierwszy utwór, albowiem pisarz zdecydował się w nim na złamanie ustalonego przez jego poprzedników „kanonicznego” mo-

19 Zob. np. D. Pilipowicz, Rozmowa o duchowym świecie. Hryhorij Skoworoda. Filozofia Teologia - Mistyka, Kraków 2010.

${ }^{20}$ Zоb. О. Осетрова, Г.С. Сковорода: старість як об’єкт філософської рефлексї̈, „Вісник Дніпропетровського університету” 2012, nr 9/2, s. 30; zob. też: В. Горський, Iсторія української філософії, Київ 2001, s. 101-124.

21 Л. Українка, Лісова пісня, [w:] еаdem, Поезія. Драматичні твори, Київ 2008, s. 129. 
delu przedstawiania seniorów, gdyż głowa tytułowego rodu Kajdaszów, Omelko Kajdasz, jest w tym przypadku uosobieniem ciemnego i zacofanego mieszkańca wsi ukraińskiej, a jego żona jawi się jako egoistka starająca się zachować absolutną władzę nad swoimi synami i ich żonami.

Nieco odmiennie starość pokazano w Zaczarowanej Deśnie (Зачарована Десна, 1956), autobiograficznej powieści Ołeksandra Dołżenki, w której pojawiły się sylwetki rodziców, dziadka, prababki, wuja Samijły. Najstarszych bohaterów wspomnianej powieści zaprezentowano najczęściej w świetle negatywnym jako niemal despotów trzymających w ryzach całą wielopokoleniową rodzinę (np. przeklinająca wszystkich i wszystko prababka). Były to wszakże typy namalowane $\mathrm{z}$ humorem, a ich wady nadawały kolorytu utworowi, wcale nie tworząc pejoratywnego odbioru starości ${ }^{22}$. Starość jest też dosyć częstym motywem występującym we współczesnej poezji ukraińskiej, by przywołać takie nazwiska, jak na przykład Maksym Rylski, Pawło Tyczyna czy Wasyl Symonenko.

Jak pisze cytowana już Agnieszka Czyżak,

dziś ostatecznie odchodzi w niepamięć kulturowy stereotyp Starego Filozofa, który u schyłku lat dochodzi do prawdziwej mądrości — w starości Mędrzec, w potocznej opinii, zmienia się w błazna, szaleńca, niepotrzebnego nikomu oraz niezdolnego przewodzić czy nauczać zdziecinniałego staruszka. Co gorsza, dzieje się tak w epoce demograficznych przemian, w której wydłużenie biologicznego trwania sprawia, że stale rosną rzesze ludzi w „trzecim wieku", emerytów, rencistów, spychanych przez kulturę masową na margines życia ${ }^{23}$.

Współczesna kultura, będąca kulturą masową i globalizacyjną, ma charakter ponadczasowy, wyzbywa się swej tożsamości historycznej, a to pociąga za sobą upadek autorytetów, gdyż — jak piszą Agnieszka Matusiak i Mateusz Świetlicki „[...] мудрішим поколінням виявляється молоде, від якого старші повинні черпати науку про те, як жити і функціонувати в суспільстві, створеному молодими за їхніми ж принципами" 24 .

Podobne tendencje przejawiają się także w kulturze i literaturze ukraińskiej, co postaramy się pokazać na przykładzie analizy powieści Lubka Deresza Namir! (Haмip!, 2006). Z formalnego punktu widzenia utwór utrzymany jest w duchu realizmu magicznego niejako na przekór twierdzeniom o śmierci tego gatunku ${ }^{25}$ i kontynuuje najlepsze tradycje literatury latynoamerykańskiej (Juan Rulfo, Gabriel García Márquez). Można go też zakwalifikować jako powieść postmodernistyczną, choć Tamara Hundorowa sugeruje, że jest to raczej przejaw swoiście rozumianego kiczu literackiego, gdyż jak pisze,

22 Рог. Т. Коваль, Дихотомія духовності і страху старості у мистеиькій практиці: ціннісний аспект, „Вісник Житомирського державного університету” 2014, z. 1 (73), s. 26.

23 A. Czyżak, op. cit., s. 12.

24 А. Матусяк, М. Свєтліцкі, Категорія покоління у сучасних суспільно-культурних дослідженнях, [w:] Постколоніалізм. Генераџіï. Культура, red. Т. Гундорова, А. Матусяк, Київ 2014, s. 137.

25 K. Mroczkowska-Brand, Przeczucia innego porzadku. Mapa realizmu magicznego w literaturze światowej XX i XXI wieku, Kraków 2009, s. 52. 
у сучасній літературі спостерігаємо повернення до естетики кітчу й активне застосування його прийомів. На сьогодні уже утвердився молодіжний кітч, представлений іменами С. Жадана, Л. Дереша, О. Ушкалова, І. Карпи ${ }^{26}$.

Badaczka dodaje jednak, że w jej rozumieniu ów kicz to „мікромодель масової культури, семіотична програма якої - імітування, копіювання та перетворення мистецтва на товар"27. Nie można nie zgodzić się z ukraińską uczoną, gdyż powieść Deresza doskonale wpisuje się w tak skonstruowaną definicję. Czwarta z kolei książka Lubka Deresza to osadzona w realiach galicyjskiego miasteczka Miedziane Buki historia chłopca obdarzonego fenomenalną pamięcią. Głównym bohaterem utworu jest Petro Piatoczkin, z którym po raz pierwszy odbiorca spotyka się, gdy ten kończy jedenaście lat. W pewnym momencie chłopiec odkrywa swój niespotykany dar i ze spektakularnym powodzeniem zaczyna wykorzystywać go w szkole. Odbiorca towarzyszy bohaterowi w czasie jego dojrzewania, obserwuje okres buntu, problemy w szkole i kolejne miłosne „zdobycze”. Stopniowo pamięć zaczyna ciążyć bohaterowi, który zaczyna mieć skłonności do filozofowania i poszukiwania światów alternatywnych. Świadom wielkiej przepaści mentalnej pomiędzy nim i rówieśnikami, rozczarowany otaczającą rzeczywistością i szukający wytchnienia przed bezlitosną pamięcią Petro udaje się do odciętej od świata wsi Chobotne, by zaopiekować się niedomagającą babcią. Narracja poprowadzona jest w taki sposób, że już pierwsze spotkanie $\mathrm{z}$ babką chłopca tworzy negatywny obraz kobiety w oczach odbiorcy:

За свій вік баба добряче попила крові й донькам, і зятям. Але це було колись, іще до старечих хвороб, до пенсії та слабості. Тепер на бабу дивилися чи то з іронією, чи 3 погано прихованим роздратуванням. Хоч ніщо на те прямо й не вказувало, рідні достроково приписали бабі старечий маразм, мабуть керуючись принципом „око за око”. [...] „Чекай-чекай, - сварилася баба Віра однаково, що тепер, що двадцять років тому. - Прийде твоя мама, я їй все скажу. Все, що про неї думаю"28.

W swej młodości staruszka była kobietą silną, władczą, stanowczą i dominującą, także nad swoim mężem-profesorem. $Z$ wiekiem jej charakter stał się na tyle uciążliwy i niezbyt przyjemny, że jej przebywające za granicą córki gotowe były nawet na przysyłanie pieniędzy na opiekunkę, byleby tylko nie spędzać czasu z gderliwą matką. Wydaje się, że również wnuk nie ma zbyt wielkiego szacunku do nestorki rodu. Bohater wie, że rodzina przysłała go do niej, żeby pozbyć się go z domu i żeby, przy okazji, wypełnić „chrześcijański obowiązek” opieki nad chorym, przyjmuje jednak ten „wyrok” ze spokojem. Jak przyznaje, ,[...] Я знав, що баба от-от помре, і для баби також це не було секретом". W związku z tym ,[...] найперше, про що я хотів спитати бабу, це коли вона збирається померти" (kursywa w oryginale, s. 60). Z przytoczonych słów z jednej strony

26 Т. Гундорова, Кітч і література. Травестї̈, Київ 2008, s. 67.

${ }^{27}$ Ibidem, s. 5.

28 Л. Дереш, Намір!, Київ 2006, s. 59. Dalej w tekście podaję w nawiasach numery stron $\mathrm{z}$ tego wydania. 
wypływa racjonalizm, gdyż starsza kobieta jest już obłożnie chora, z drugiej zaś uderza cynizm i bezwzględność, z jakimi wnuk potraktował swą babcię. W jego zachowaniu nie widać współczucia ani szacunku dla starszej osoby. Wydaje się, że takie czynności, jak gotowanie, czytanie babce i pomoc przy codziennych czynnościach wykonuje automatycznie, z chłodną obojętnością. Mimo braku głębszych uczuć, Petro codziennie zajmuje się swoją babką, sprząta, pierze, chodzi po zakupy, wykonuje przy niej czynności pielęgnacyjne, które można by uznać za odpychające. Czyta jej nawet na głos Pismo Święte:

Зранку баба мала духовне життя: молилася, слухала Біблію в моєму озвученні. Віддавала перевагу радісному Новому Заповіту, здебільшого посланням апостола Павла. Святий апостол Павло був бабиним улюбленцем, i вона вкотре просила зачитати його послання до коринтян, задоволено при цьому рухаючи губами, ніби смакувала кожне слово.

Після обіду у неї починалося життя мирське - баба слухала прямі включення Верховної ради по радіо „Промінь”, куняла чи просто лежала на ліжку, знову таки, молячись (s. 61).

Początkowo odbiorca może odnieść wrażenie, że w gruncie rzeczy wnuk nie jest jednak pozbawiony odrobiny empatii, że jest jak bohater Tadeusza Różewicza z tomu Matka odchodzi, który stanąwszy wobec faktu odchodzenia swej rodzicielki, opiekuje się nią, nie myśląc nawet o uwolnieniu się od tego obowiąz$\mathrm{ku}^{29}$. Można by było się pokusić o porównanie go także do protagonisty Jacka Dehnela opisującego w swej powieści pt. Lala proces utraty pamięci, a więc i tożsamości, ulubionej nestorki rodu wymagającej nieustannej opieki ${ }^{30}$, czy chorego na chorobę Alzheimera sędziwego ojca bohatera utworu Arno Geigera, który pomimo choroby odzierającej człowieka z godności, nadal zachowuje pełnię człowieczeństwa ${ }^{31}$. Głębsza analiza dowodzi jednak, że motywy, jakimi kieruje się Petro, są zgoła inne. Chłopiec traktuje babcię obcesowo i lekceważąco. Otwarcie prezentuje postawę konfrontacyjną, a przy tym okazującą wyższość młodzieńczej siły wobec coraz bardziej bezradnego i starzejącego się człowieka. Lekceważenie staruszki przejawia się już w samym sposobie określania harmonogramu jej dnia, który oscyluje pomiędzy poranną modlitwą, słuchaniem radia i drzemką. Powstaje więc wrażenie, że każdy starszy człowiek a priori „nadawał się" już tylko do przysłowiowego „klepania zdrowasiek pod piecem”. Zresztą już sam sposób przedstawienia postaci starszej kobiety w analizowanej powieści Deresza nie pozostawia złudzeń i doskonale wpisuje się w ramy wyznaczone przez wcześniejsze rozważania teoretyczne. Dereszowska starość jest brzydka i nieatrakcyjna: wyłaniająca się z utworu osoba ma nie tylko okropny charakter, ale też skrzypiący głos, a na podbródku — „wielką szarą brodawkę” (s. 60), co w wyobraźni odbiorcy może ewokować obraz wiedźmy i w naturalny sposób wywoływać antypatię, a nawet strach. Jej ciało powoli się rozpada, a następstwem

${ }^{29}$ Zob. T. Różewicz, Matka odchodzi, Wrocław 1999.

30 Zob. J. Dehnel, Lala, Warszawa 2011.

${ }^{31}$ A. Geiger, Stary król na wygnaniu, Warszawa 3013. 
tego postępującego rozpadu jest utrata sił, przy czym posunięta tak dalece, że staruszka nie jest w stanie podnieść się z łóżka na więcej niż dwie godziny, a na dodatek ciągle marznie. Autor odziera kobietę z godności, przedstawia jako osobę pełzającą na czworakach i niedającą sobie rady z samodzielnym załatwianiem potrzeb fizjologicznych:

- Петру-усю!.. Йой... Петру-у-усю! Я кинувся до баби. Баба сиділа на підлозі в калюжі сцяків і плакала. За метр від неї стояв горщик, якого я, остолоп, забув підсунути ближче. —Йо-о-ого-ой... - ревіла баба і розмазувала соплі по лицю. [...] (s. 273).

Takie przedstawienie odpowiada zatem opisanej powyżej, sformowanej w antyku koncepcji starców i starości jako nieatrakcyjnej i prowadzącej do zdziecinnienia ${ }^{32}$. Odbiorca może poczuć się jeszcze bardziej skonsternowany, kiedy orientuje się, że główny bohater powieści bezwzględnie wykorzystuje swą młodzieńczą przewagę nad babką i występuje w roli jej dręczyciela. Jak pamiętamy, ulubionym jej fragmentem Biblii był List św. Pawła do Koryntian. Możemy znaleźć zrozumienie dla tego faktu, albowiem człowiek zmierzający ku nieuchronnemu końcowi żywota może znaleźć tam ukojenie ze względu na obietnicę przyszłego życia: „Wiemy bowiem, że jeśli nawet zniszczeje nasz przybytek doczesnego zamieszkania, będziemy mieli mieszkanie od Boga, dom nie ręką uczyniony, lecz wiecznie trwały w niebie" (2 Kor 5,1). Słowa te pozwalają zatem mieć nadzieję, że ułomność cielesną na ziemi zrekompensuje nagroda w Niebie i w ten sposób łagodzić sobie oczekiwanie na to, co nieuniknione, gdyż przecież „śmierć fizyczna jest wejściem w życie wieczne"33. Tymczasem wnuk często rozmawia z babcią o śmierci, choć ona otwarcie unika takich rozmów, a na dodatek zaczyna czytać jej znalezioną w gabinecie dziadka-profesora książkę Eliadego o rytuałach pogrzebowych (s. 66) i Tybetańska księgę umarlych. To wywołuje naturalny, podszyty strachem, sprzeciw staruszki, która wciąż kurczowo trzyma się życia:

В основному балакали про смерть. Мені хотілося знати, як баба сприймає факт, що от-от помре. Перший раз бабця всіляко переводила стрілки: розповідала про своїх дітей і все, що вона про них думає [...]. Коли ж я вольовим зусиллям перевертав бесіду в потрібне русло, баба плакала [...]. Першого ж дня довелося запевнити стару, що ніхто за нею побиватися не буде. Вона по-дитячому здивувалася: „Як ніхто?”

„А так ніхто”, - відрубав я. Баба знову розплакалась. У перші дні нашого знайомства баба часто плакала (s. 62-63).

Wydaje się jednak, że każąc wnukowi znęcać się nad babką, autor ukrył jeszcze jakieś dodatkowe znaczenie. Uważny odbiorca odnajdzie ukryte głęboko przesłanie, że takie niehumanitarne zachowanie młodzieńca względem kobiety nie jest po prostu zwykłym okrucieństwem, lecz podjęciem próby przygotowania jej do momentu „przejścia” do wieczności. Pewnego dnia bohater odnalazł w gabinecie swego dziadka klepsydrę i postanowił przetestować ją na swej babce:

32 Por. G. Minois, op. cit.

33 P. Ariès, Człowiek i śmierć, Warszawa 2011, s. 107. 
Коли баба вчергове зайшлася плачем, я повернувся із приладом і поставив його на стіл. Баба припинила плач. Стежила, що я роблю.

А я просто перевертав клепсидру, коли весь пісок з верхньої частини пересипався в нижню.

Баба не витримала. Почала вимагати, щоб я пояснив свої дії.

Я мовчки перевертав клепсидру. Баба побачила, що я не реагую на неї, скривилася і затягла своєї: „Г-і-і-і-і-і... ніхто мене не любе-е-е...”

Тоді я сказав, що один період пересипання триває шістдесят секунд. А вона вже плаче впродовж семи періодів. Чи їх це нічого не говорить? - поцікавився я. Стара схлипнула, Глянула безнадійно (s. 63).

Doświadczenie z klepsydrą sprawiło, że starsza kobieta zaczęła wreszcie zdawać sobie sprawę z nieuchronnie płynącego czasu, który w jej przypadku prowadził do nieodwołalnej, nieodwracalnej i szybko zbliżającej się już śmierci. Eksperyment Petra doprowadził do tego, że babka ostatecznie zdała sobie sprawę z bliskiego końca, mogła więc oswoić się z egzystencjalnymi myślami i należycie przygotować się do czekającej ją ostatniej drogi. Okazuje się, że wnuk, być może w niezbyt delikatny sposób, odegrał rolę mitycznego Charona przewożącego dusze zmarłych na „drugą stronę” legendarnego Styksu. Stał się swego rodzaju przewodnikiem ułatwiającym rytuał „przejścia”, albowiem — jak pisał Mircea Eliade — w śmierci chodzi nie tylko o ,jakieś zjawisko naturalne (życie — czy dusza - opuszcza ciało), lecz o ontologiczną i zarazem społeczną zmianę trybu życia. Człowiek umierający musi stawić czoło pewnym próbom decydującym o jego losie po śmierci, musi być jednak także uznany i przyjęty przez społeczność umarłych"34. Przygotowując babkę do ostatniej podróży, wnuk czytał jej przed snem wspomnianą Tybetańska księge umartych. Kiedy kobieta płakała i prosiła o lekturę Biblii, jej opiekun wyjaśniał, że Pismo Święte już przecież dobrze zna, a o tej księdze słyszy po raz pierwszy. Takie rozumowanie przypomina nieco zakład Pascala, który sugeruje, że wiara bardziej się opłaca, gdyż człowiek — nie wierząc — potencjalnie ryzykuje życie wieczne ${ }^{35}$, ergo — czytanie innych ksiąg umarłych jawi się jako dodatkowe zabezpieczenie w obliczu śmierci na wypadek, gdyby po „tej drugiej stronie” był jeszcze jakiś ,alternatywny bóg”:

А людина перед лицем смерті, продовжив я, котра знає про дві версії потойбічного, має удвічі більше шансів померти вдало (назвімо це так), ніж людина, зашорена тільки одною. Бо ніхто з живих не знає напевне, що є після смерті.

Баба заперечила, що Бог знає. Я їй на те: знає, але не каже. А чекає, щоби ми самі все побачили.

Баба замислилась. I тут несподівано спитала, що на мою думку, стається після смерті. Трохи подумавши, сказав, як вважав. „Гадаю, після смерті стається смерть” (s. 83).

Rozważania o kresie ziemskiej wędrówki sprawiają, że w końcu i sam Petro zaczyna zdawać sobie sprawę z nieuchronności własnego losu. Jak mówi, „рано

${ }^{34}$ M. Eliade, Sacrum i profanum. O istocie religijności, Warszawa 1999, s. 152-153.

35 D. Leszczyński, Filozofowie i ich filozofie. Opowieści dla niewtajemniczonych, Wrocław 2002, s. 126; zob. też: B. Pascal, Myśli, tłum. T. Boy-Żeleński, Warszawa 2001, s. 19. 
чи пізно, але й мені теж судилося підійти до магічної лінії смерті. До лінії, за якою закінчується віра, а починається досвід невідомого" (s. 86). То doświadczenie sprawiło, że bohater zaczyna patrzeć na swoją babcię w inny sposób, zaczyna widzieć w niej człowieka, nie zaś tylko męczący i odarty z godności ludzki wrak. Zaczynają go szczerze, jak się wydaje, niepokoić babcine majaczenia, ostre bóle brzucha, cieszą natomiast jej maleńkie „zwycięstwa”, jak choćby znalezienie sił do gderania czy poprawa apetytu. Ze zdumieniem widzimy radosne przygotowania do wyprawy do miasta, gdzie chłopiec planuje zrobić zakupy, aby ugotować babci barszcz, bo właśnie go sobie zażyczyła (s. 268).

Zmiana nastroju wnuka sprawiła, że babcia chciała, by był przy niej w momencie śmierci:

— Петре! — почувся розпачливий голос баби. — біжи скоро!

— Шо?! Ну шо ти хочеш?!

- Ходи сюда! Я вмираю!

Я метнувся до баби в кімнату. Вона хапала ротом дихання, але щоразу ковток ставав менший.

— Теперка вже точно... Йой, як я ся бою... Йой, Петрусю золотенький... йой, рибонько...

3 кожним „йой” з неї вилітало по кухлику сили. І вилітало по чорній пташці. Я бачив на власні очі, як ті пташки, схожі на дроздів, влітають їй у живіт.

Я сів біля баби. Серце моє аж вискакувало.

— Зара... ше б трохи... Ше би трошечки пожити... (s. 278).

Śmierć podopiecznej zmienia też samego bohatera, który nareszcie odnajduje spokój i sens życia.

Jak widzimy, utwór Lubka Deresza jest daleki od jednoznaczności w przedstawianiu starości, motywu odchodzenia i kontaktów międzypokoleniowych. Na początku przeważa deprecjacja starości, tak doskonale widoczna w kulturze masowej ostatnich dziesięcioleci, o której Andrzej Stasiuk napisał, że

w upiornym strachu przed śmiercią usunęła całkowicie ze swego imaginarium wyobrażenie starca. Szepcząc swoje magiczne zaklęcia, czci herosów, którzy umierają młodo, a tym samym oddala widmo śmierci, jako coś powszechnego i nieuniknionego ${ }^{36}$.

Daje się wychwycić wrogość młodości wobec starości i rozkładu z całą jej brzydotą ${ }^{37}$. Pisząc o tym, Simone de Beauvior stwierdziła, że „każde społeczeństwo chce żyć, przetrwać, wysławia krzepę i płodność, nieodłączne od młodości; obawia się zużycia i jałowości, jakie cechują starość"38. Zgadzając się niejako z francuską pisarką, należy przyznać, że powieść Deresza to hymn młodości i siły, brutalna konfrontacja ze starością, która zasługuje jeśli nie na pogardę, to przynajmniej na politowanie i lekceważenie. Z drugiej strony wspólne przeżycia sprawiają, że bohater zmienia stosunek do swej babki, staje się z czasem wyrozumiały i ostatecznie pomaga jej w odchodzeniu, zaczyna bowiem rozumieć, że

\footnotetext{
${ }^{36}$ A. Stasiuk, O starości i śmierci, [w:] idem, Tekturowy samolot, Wołowiec 2002, s. 69.

37 Por. W. Menninghaus, op. cit., s. 110-122.

38 S. de Beauvoir, La Viellesse, Gallimard 1970, s. 47, cyt. za: G. Minois, op. cit., s. 323.
} 
za jakiś czas sam podąży tą samą ścieżką. Petro zdaje sobie sprawę, że starość oznacza samotność i wykluczenie ze świata oraz skazanie na niezrozumienie. Pojawia się więc iskierka szacunku do starej kobiety i niepokój, że jego samego też kiedyś może spotkać ten sam los.

Podsumowując, należałoby jeszcze raz podkreślić, że analizowana powieść Lubka Deresza jest wyraźnym produktem epoki postmodernistycznej kultury masowej, jeśli chodzi o sposób ujęcia zagadnienia starości. Sygnalizuje jednak pewną zmianę podejścia, w którym wyczuwalna jest próba zrozumienia sytuacji osób w podeszłym wieku. I choć Roksana Charczuk stwierdziła, że „[...] література Л. Дереша - це, звичайно, сублітература, розрахована на освічену молодь, так званих неформалів або тих, хто хоче ними бути, кого не влаштовують стандарти масового або попсового суспільства" ${ }^{\text {"39 }}$, a do całej jego twórczości zarówno czytelnicy, jak i krytycy podchodzą niejednoznacznie ${ }^{40}$, to wydaje się, że tak ujęte przez pisarza zagadnienie starości pozwala umieścić Namir! obok takich utworów, jak chociażby wspomniana już Lala Jacka Dehnela, Matka odchodzi Tadeusza Różewicza, Stary król na wygnaniu Arno Geigera, a na gruncie ukraińskim - Stulecie Jakuba Wołodymyra Łysa ${ }^{41}$, gdzie sędziwy, stuletni bohater, jest centralną postacią tej retrospektywnej powieści.

\section{Bibliografia}

Ariès P., Człowiek i śmierć, Warszawa 2011.

Czyżak A., Na starość. Szkice o literaturze przełomu tysiacleci, Poznań 2011.

Dehnel J., Lala, Warszawa 2011.

Delumeau J., Przedmowa, [w:] G. Minois, Historia starości. Od antyku do renesansu, Warszawa 1995.

Dragan A., Starzenie się społeczeństwa polskiego i jego skutki, „Opracowania Tematyczne” OT-601, Kancelaria Senatu, Biuro Analiz i Dokumentacji, kwiecień 2011.

Eliade M., Sacrum i profanum. O istocie religijności, Warszawa 1999.

Geiger A., Stary król na wygnaniu, Warszawa 3013.

Giddens A., Socjologia, Warszawa 2008.

Jurkiewicz J., Kiedy w starożytności rozpoczynała się starość?, „Vox Patrum” 56, 2011.

Leszczyński D., Filozofowie i ich filozofie. Opowieści dla niewtajemniczonych, Wrocław 2002.

Menninghaus W., Wstręt. Teoria i historia, Kraków 2009.

Minois G., Historia starości. Od antyku do renesansu, Warszawa 1995.

Modrak M., Trzeci poziom dojrzałości. Szczęśliwe życie po sześćdziesiątce, Gliwice 2013.

Mroczkowska-Brand K., Przeczucia innego porzadku. Mapa realizmu magicznego w literaturze światowej XX i XXI wieku, Kraków 2009.

Nowicka E., Świat człowieka - świat kultury, Warszawa 2004.

Pascal B., Myśli, tłum. T. Boy-Żeleński, Warszawa 2001.

39 Р. Харчук, Сучасна украӥнська проза. Постмодерний період, Київ 2008, s. 224-225.

40 Zob. М. Данилюк, Роман про подорож у пам'ять, або намір нескінченності (за твором Любка Дереша „Намір!”), „Наукові записки Національного університету Острозька академія". Серія філологічна 2003, z. 32, s. 56.

41 Zob. В. Лис, Століття Якова, Харків 2013. 
Pilipowicz D., Rozmowa o duchowym świecie. Hryhorij Skoworoda. Filozofia - Teologia - Mistyka, Kraków 2010.

Podbielski H., Starość i starcy w poematach Homera, [w:] Dojrzewanie do petni życia.Starość w literaturze polskiej i obcej, red. S. Kruk, E. Flis-Czerniak, Lublin 2006.

Rosset E., Miejsce człowieka starego w społeczeństwie, [w:] Encyklopedia seniora, red. I. Borsowa, W. Pędlich, J. Piotrowski, Warszawa 1986.

Różewicz T., Matka odchodzi, Wrocław 1999.

Stasiuk A., Tekturowy samolot, Wołowiec 2002.

Zmorzanka A., Platon o starości i ludziach starych, „Vox Patrum” 56, 2011.

Горський В., Історія української філософії, Київ 2001.

Гундорова Т., Кітч і література. Травестії, Київ 2008.

Данилюк М., Роман про подорож у пам'ять, або намір нескінченності (за твором Любка Дереша „Намір!”), „Наукові записки Національного університету Острозька академія”. Серія філологічна 2003, z. 32.

Дереш Л., Намір!, Київ 2006.

Коваль Т., Дихотомія духовності і страху старості у мистецькій практиці: иіннісний аспект, „Вісник Житомирського державного університету” 2014, z. 1 (73).

Лис В., Століття Якова, Харків 2013.

Матусяк А., Свєтліцкі М., Категорія покоління у сучасних суспільно-культурних дослідженнях, [w:] Постколоніалізм. Генерації. Культура, red. Т. Гундорова, А. Матусяк, Київ 2014.

Осетрова О., Г.С. Сковорода: старість як об’єкт філософської рефлексї, „Вісник Дніпропетровського університету" 2012, nr 9/2.

Українка Л., Поезія. Драматичні твори, Київ 2008.

Харчук Р., Сучасна украӥнська проза. Постмодерний період, Київ 2008.

\section{Youth to old age: respect or depreciation? Namir! by Lubko Deresh}

\section{Summary}

This article deals the problem of old age in the novel Namir! by Ukrainian writer Lubko Deresh. To accomplish this research task, at the beginning of the presentation problem of how the elderly was presented in culture and literature over the centuries was analyzed, and then was analyzed the novel itself. Studies have shown that in his book the author raised the question of a confrontation of youth with an old age. Our analyzes of Namir! by Deresh turned out that it repeats the patterns of mass culture, showing a tendency to devaluation the elderly. During the study revealed, however, a change in approach to the problems of old age, which is visible attitude of respect for the elderly linked to equality in the face of inevitable death.

Keywords: youth, old age, depreciation, disgust, mass culture

Slavica Wratislaviensia 163, 2016

(C) for this edition by CNS 


\section{Молодість перед старістю: пошана чи зневага? Намір! Любка Дереша}

\section{Резюме}

Метою цієї статті є спроба показати проблему старості в романі українського письменника Любка Дереша Намір! Щоб успішно висвітлити так окреслене завдання, на початку було звернено особливу вагу на те, як питання старості представлялося культурою та літературою протягом століть, і тільки тоді було звернено увагу на саму повість. Дослідження показали, що в своїй книзі автор використав питання конфронтації молодого віку із старістю. Під час аналізу нами було встановлено, що Намір! повторює схеми масової культури та показує виразну схильність автора до девальвації літніх людей. Наше дослідження показало, однак, певну зміну в підході до проблеми старості, а саме, що зміна зневаги на ставлення з повагою до літніх людей пов'язана із рівністю всіх людей перед обличчям неминучої смерті.

Ключові слова: молодь, старість, зневага, відраза, масова культура 